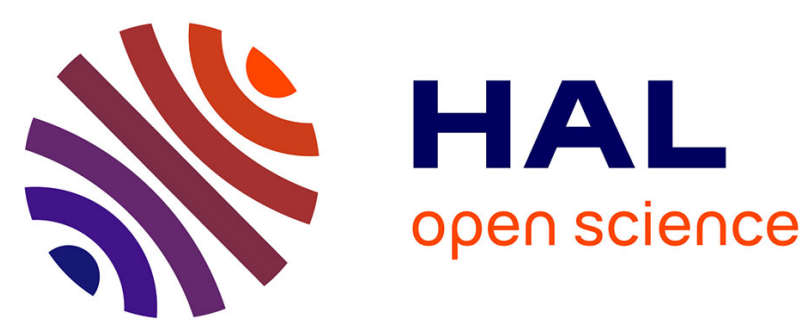

\title{
A study of late Holocene local vegetation dynamics and responses to land use changes in an ancient charcoal making woodland in the central Pyrenees (Ariège, France), using pedoanthracology
}

Mélanie Saulnier, Raquel Cunill Artigas, Léonel Fouedjeu Foumou, Sandrine Buscaino, Jean-Paul Métailié, Didier Galop, Vanessa Py

\section{To cite this version:}

Mélanie Saulnier, Raquel Cunill Artigas, Léonel Fouedjeu Foumou, Sandrine Buscaino, Jean-Paul Métailié, et al.. A study of late Holocene local vegetation dynamics and responses to land use changes in an ancient charcoal making woodland in the central Pyrenees (Ariège, France), using pedoanthracology. Vegetation History and Archaeobotany, 2020, 29, pp.241-268. 10.1007/s00334-019-00740-7 . hal-02485838

\section{HAL Id: hal-02485838 \\ https://hal-univ-tlse2.archives-ouvertes.fr/hal-02485838}

Submitted on 20 Feb 2020

HAL is a multi-disciplinary open access archive for the deposit and dissemination of scientific research documents, whether they are published or not. The documents may come from teaching and research institutions in France or abroad, or from public or private research centers.
L'archive ouverte pluridisciplinaire HAL, est destinée au dépôt et à la diffusion de documents scientifiques de niveau recherche, publiés ou non, émanant des établissements d'enseignement et de recherche français ou étrangers, des laboratoires publics ou privés. 


\title{
A study of late Holocene local vegetation dynamics and responses to land use changes in an ancient charcoal making woodland in the central Pyrenees (Ariège, France), using pedoanthracology
}

\author{
Melanie Saulnier ${ }^{1,2}$, Raquel Cunill Artigas ${ }^{3}$, Leonel Fouedjeu Foumou ${ }^{1}$, \\ SANDrine Buscaino ${ }^{1}$, JeAn-Paul Metailie ${ }^{1}$, Didier GaloP ${ }^{1}$, VANessa Py- \\ SARAGAGLIA $^{1}$ \\ ${ }^{1}$ Research fellow LABEX DRIIHM, GEODE UMR5602 CNRS Université \\ Toulouse Jean Jaurès, 5, Allées A. Machado, 31058 Toulouse Cedex 1, France, e- \\ mail:melanie.saulnier14@gmail.com \\ ${ }^{2}$ Czech University of Life Sciences of Prague, Department of Forest Ecology, \\ Kamýcká 129, 16500 Praha 6-Suchdol, Czech Republic \\ ${ }^{3}$ Department of Geography, Edifici B, Facultat de Filosofia i Lletres, Universitat \\ Autonoma de Barcelona, 08193 Bellaterra (Cerdanyola del Valles), Spain
}

\begin{abstract}
Human activities have profoundly transformed mountain woodland landscapes, particularly in the Pyrenees where they have intensified and diversified since the Bronze Age. Quantification of the role played by past practices with regard to woodland cover is critical for accurate assessment of how ongoing global environmental change may affect its dynamics in the future. A local study was made of charcoal remains from an ancient charcoal-making woodland (ca. 30 ha), the forêt de Bernadouze, located on a north-facing slope in the Vicdessos valley in the French central Pyrenees. This valley is well known as having had a long history of human influence related to pastoralism, iron ore mining and smelting. A total of 1,695 charcoal pieces from soils in three sampling pits was extracted, identified, quantified and dated in order to identify tree canopy openings and patterns of change in the woodland driven by past human uses. The results provide new and original insights regarding 1, the past higher biodiversity and the ancient character of the foret de Bernadouze, 2, the dynamics and history of the main trees and 3, successive phases of human activity. We show that the current woodland has resulted from several millennia of human activities such as pasturing and use of the wood for making charcoal. From the Bronze Age, humans have progressively transformed a natural fir-dominated wood into a managed beech-dominated one, and caused the elimination of Taxus baccata L. (yew).
\end{abstract}


Keywords Local scale study · Late Holocene · Central Pyrenees · Vegetation dynamics $\cdot$ Land use changes $\cdot$ Soil charcoal analysis

\section{Introduction}

The history of the Pyrenean woodlands has been investigated for several decades, especially by means of pollen analyses (Kenla 1977; Jalut et al. 1982, 1998; Reille and Lowe 1993; Galop and Jalut 1994; Galop 1998; Ejarque et al. 2010; Pèlachs et al. 2011; Galop et al. 2013; Garcés-Pastor et al. 2017; González-Sampériz et al. 2017). These demonstrated the effects of both climatic change and human activity on major vegetation changes from the end of the last glacial period. While the climate was the main driver controlling earlier vegetation change, human pressure has played a major role since the mid Holocene (Galop et al. 2013). Some multiproxy studies have provided a basis for accurate assessment of vegetation changes caused by human activities (Galop et al. 2003, 2013; Bal et al. 2011). Woodland pasturing and farming in combination with mining activities from the Bronze Age onwards have led to the significant reduction and/or transformation of the tree cover (Galop et al. 2001). The spread of Fagus sylvatica L. (beech) and the drastic reduction of Abies alba Mill. (fir) are the most widely reported changes in the northern Pyrenees (Kenla 1977; Jalut 1984; Galop and Jalut 1994; Galop et al. 2003). Since Gallo-Roman times (between the 1st century BC and the 4th-5th century AD), and especially from the end of the medieval period (ca AD 1500), mining and metallurgical processes are known to have caused further changes in woodland distribution, structure and composition (Camarero et al. 1998; Davasse 2000; Dubois and Métailié 2001; Rius et al. 2012; Py-Saragaglia et al. 2017). But from these data, it remains difficult to accurately characterise these processes with high spatial resolution, which are very variable from one upper valley to another (Galop and Jalut 1994). Unlike palynology, pedoanthracology (soil charcoal analyses) make it possible to identify the appearance or disappearance of woody taxa and to characterise woodland cover dynamics at a very local level (Touflan et al. 2010; Saulnier et al. 2015; Feiss et al. 2017a). This discipline has been already used in the Pyrenees to study tree line variation (Cunill et al. 2012, 2013) and the creation of cultivation terraces in high mountain areas (Bal et al. 2008). However, few soil charcoal studies have been done in the woodlands of the northern Pyrenees (Cunill et al. 2015; Py-Saragaglia et al. 2017). The aim of this work is to 
make a modest contribution towards improving this deficiency in the Vicdessos valley, a region otherwise well covered by previous palaeoecological studies. This valley, located in the eastern part of the French central Pyrenees (Ariège, Fig. 1), has been a site of long-term and iron and steel making activities, as reported by earlier archaeological and historical studies (Davasse 2000; Dubois and Métailié 2001; Verna 2001). Several pollen analyses of peat and lake sediment sequences (Jalut et al. 1982; Reille 1993; Reille and Lowe 1993; Galop and Jalut 1994), and soil charcoal studies of former charcoal making sites (Davasse 2000), have provided essential information for understanding vegetation changes related to human activities on the valley scale. Furthermore, since 2009 a HumanEnvironment Observatory (Labex - Laboratory of Excellence - DRIIHM) has been in operation in this valley and its surroundings. For this, the peatland site of Bernadouze (Fig. 1) (incorrectly called "Freychinède" in former studies) and its surrounding woods were instrumented to monitor environmental conditions and climate by the Haut-Vicdessos Observatory. This area, located in the northwestern part of the Suc-et-Sentenac upper valley, has also been a managed biological reserve since 1983. It is composed of the woodland plot $\left(\mathrm{n}^{\circ} 106\right)$ of the Bernadouze peat area (3.81 ha) and a 90 ha buffer zone consisting of woodland (the western part of the forêt dominiale de Suc-et-Sentenac) (Fig. 1). As part of the management plan, an anthracological study (analysis of charcoal) from ancient charcoal making sites is currently being done to characterise woodland uses and to measure the impact of past charcoal making on the woodland ecosystem (PySaragaglia et al. 2018).

However, this approach does not enable us to go back before the end of the Carolingian era (ca AD 800-1000). On the other hand, a mid Holocene vegetation reconstruction with very fine time resolution from a new multi-proxy analysis of the Bernadouze peat bog sequence is not possible, because the peat was extracted in the 19th century (Jalut et al. 1982). Consequently, to overcome this limitation, and for the purpose of reconstructing the long-term changes of the local vegetation both from natural events and human activities, we have carried out this preliminary local scale pedoanthracological study, based on soil charcoal from three sampling pits. The main purpose of this paper is thus to contribute to the understanding of the woodland dynamics at forêt de Bernadouze before charcoal burning, but also, independently of this, to test the application of soil charcoal 
analysis here. This paper therefore provides evidence for the relevance of a pedoanthracological study carried out in a woodland formerly used for charcoal making. Due to the high risk of the transfer of materials from charcoal kiln terraces to soils, this context remains unusual for this discipline, but it has proved very interesting (Knapp et al. 2013; Py-Saragaglia et al. 2017). More specifically, by combining our results with other available palaeoecological and archaeological data, this paper aims to discuss 1 , changes in the composition and structure of the tree cover since the mid Holocene, 2, fire events from natural or human sources, the type of burnt woodland and canopy openings, and 3, the age of the tree cover and its degree of maturity reached in the past.

\section{Study area}

\section{The upper valley: current general characteristics}

The Suc-et-Sentenac valley is the northernmost of the Vicdessos sub-valleys in the Pyrenees, and it marks the junction between the iron deposits in the Devonian dolomites and the granitic and metamorphic north Pyrenean massif of the Trois Seigneurs (Fig. 1). The Suc-et-Sentenac upper valley follows the course of one of the major faults which form part of the north Pyrenean fault system. The study area is located at the point where four main geological formations meet, granites in the north, Jurassic dolomites in the south, migmatites (mixture of metamorphic and igneous rock) in the west and limestone in the east. The overlapping of limestone and lherzolites (ultramafic igneous rocks) gives the area a special geomorphological character with specific patterns.

The valley was wholly covered by the Ariège glacier during the last glacial maximum and during part of the deglaciation (Jalut et al. 1982), which has strongly contributed to shaping the relief. The moraine terraces from this period are widespread in the downstream part, but their remains can be found as far upstream as the Bernadouze peat bog. The Lhers mountain pass was a watershed between the Vicdessos and Aulus glaciers at the last glacial maximum. Soils of the Bernadouze watershed have developed on recrystallized limestone with numerous rocky outcrops. The most common soils observed within the woodland are rendisols (on calcareous rock), calcisols (with a substantial secondary accumulation of lime) and brunisols (brown earths). They are 
characterised by a silty-clayey texture in various proportions and by basic $\mathrm{pH}$ values. As is the case with woods in temperate regions, the soil is of a brown colour, darker or lighter depending on the amount of organic matter in it. The soil profiles in the sampling pits showed some red pockets of varying sizes due to oxidized iron minerals.

The southern slopes are gentle, while the northern slopes are often very steep. Since the highly crystalline rocks across the Pyrenees form a natural barrier to air masses, the upper valley has a specific microclimate in which oceanic, mountain and Mediterranean influences interact (Jalut et al. 1992).

\section{The western part of the forêt dominiale de Suc-et-Sentenac}

The forêt dominiale de Suc-et-Sentenac (state forest) covers 630.34 ha between $800 \mathrm{~m}$ and 1,885 $\mathrm{m}$ within the upper Suc-et-Sentenac valley (Fig. 1). The northwestern part, often referred to as 'Freychinède', owes its name to that of the forest sector in the 1669 'triage de Fraissinède' and became 'Quartier de Freychined' in 1807. Our specific study area is included within this forêt de Freychinède, but it comprises the managed biological reserve of Bernadouze and the part of its buffer zone surrounding the peat bog which is known as forêt de Bernadouze by forest managers (Figs. 1, 2). It extends between 1,350 and 1,600 m and covers around 32 ha.

\section{Current woody vegetation}

The natural environment favours a rich flora with mountain as well as Mediterranean and oceanic taxa. On south-facing slopes, opposite our study area, apart from the small oak wood with Quercus pubescens Willd. and Q. petraea (Matts.) Liebl. at Les Bordes around 1,500-1,600 m, the landscape is dominated by ancient farmland now partially colonised by secondary heath vegetation with Cytisus scoparius L. (common broom), Juniperus communis L. ssp. communis and nana (junipers) and Ericaceae such as Calluna vulgaris Hull. (heather) (Fig. 2), with summer pasture above this. Fraxinus excelsior L. (ash), Salix (willow), Betula pendula Roth. (silver birch) and Corylus avellana L. (hazel) grow at the foot of the slopes and along rivers and streams.

The woodland surrounding the peat bog is located on the northern side of the Bernadouze watershed, between 1,350 and $1,650-1,700 \mathrm{~m}$. It is mainly composed 
of Fagus sylvatica (beech) forming monospecific stands of mature woodland and tall growing coppiced trees around 100-150 years old (Fig. 2). Gaps in the tree canopy are colonised by some Sorbus aucuparia L. (rowan), S. aria L. (whitebeam) and Abies alba (fir). The understory and shrub vegetation are mainly composed of ferns, mostly Pteridium aquilinum L., some Sambucus racemosa L. (elderberry), Ilex aquifolium L. (holly) and Ericaceae such as Vaccinium myrtillus L. and Rhododendron ferrugineum L. At the upper limit of the woods around $1,650-1,700 \mathrm{~m}$, there is a stand of conifers composed of Pinus uncinata Mill. ex. Mirb. (mountain pine), Abies alba and Picea abies L. (spruce), from plantations (Fig. 2).

\section{Past vegetation changes documented by historical texts and maps}

Between the second half of the 17th century and the beginning of the 19th century, the patterns of change within forêt de Freychinède, roughly corresponding to the northern slope of the Suc-et-Sentenac valley, are recorded by two reports, illustrated by a map drawn by Louis De Froidour (1669) during the reformation of the Water and Forests Office in 1669 for the Vicdessos area, and the minutes written in 1807 by Dralet, the Conservator of Water and Forests (Dralet 1807). These documents have been the subject of a first ecohistorical study by Davasse (2000, pp 87-118).

The reports of Louis de Froidour are inaccurate and incomplete, especially with regard to the upstream part of the Suc-et-Sentenac valley. According to the surveyors, Fagus and Abies were the main trees there, but with rare exceptions, they did not constitute real Fagus-Abies woods.

Fagus was present everywhere, but only in the form of coppices in most cases described as "degraded" and beech constituted the major part of the woods on the northern and north-western slope. Fir trees were located on the inaccessible summits where they were 'sparse' or mixed with Fagus. Pure Abies stands were mainly present in the downstream portion of the Vicdessos basin, on northern slopes of accessible valleys. This location, which is not consistent with the bioclimatic model, was related to the location of the main centres of consumption, where firs were planted and managed for timber. Obtaining firewood and timber as well as making charcoal are mentioned in almost all the woods visited by 
surveyors, but we do not have specific reports for our study area. Davasse (2000) assumed that the upstream part of the Vicdessos basin was devoted to making charcoal for supplying forges from at least the end of the 16th century; in the mid 17th century, there were six forges around the main basin. The first results of archaeological investigations have shown that charcoal burning started earlier in our study area, at least by the 14th century and intensified between the 15th and 17th centuries (Py-Saragaglia et al. 2018). The last charcoal maker worked in Bernadouze in the 1930s. A total of 81 charcoal kiln terraces have been discovered over an area of around 30 ha and sampled for the ongoing anthracological analyses (Fig. 1). Overall, the first results show almost exclusive use of Fagus in the 14th-15th centuries, then a combined use of Fagus and Abies, with Abies dominating in the northern sector and Fagus in the other two, between the 15 th and 17 th century. The charcoal kiln (4) clearly later than the18th century shows almost exclusive use of Fagus.

At the beginning of the 19th century, Dralet (1807) described woodlands in poor condition with a mosaic of different trees (Davasse 2000). On southern slopes, he showed 1, the spread of cultivated fields and meadows and 2, the disappearance of beech copses which had changed into "pastures and waste lands" or "cultivated fields and meadows". At the top of these areas grew a stand of Quercus, which still partially exists today at Les Bordes. The proceedings of the rural council of Vicdessos showed that this oak stand was protected before 1762, after which it was subject to land clearing. On northern and northwestern slopes, Dralet described 1, Fagus copses changed into mature beechwoods and 2, Abies mixed with Fagus remaining in the north-western extremity of the woods. But a comparison between the two documents indicates the decline of the Abies stands between 1669 and 1807. Moreover, the wooded area located on the northern slopes of the Suc-et-Sentenac valley, described as "degraded" in 1669, was considered as "ruined" in 1807.

\section{Patterns of change in the Holocene vegetation indicated by previous palaeoecological studies}

The pollen analysis of the Bernadouze peat bog, from which all dates have been calibrated with OxCal v. 4.3, showed that the Post-glacial period began in the valley around $12,542 \pm 182 \mathrm{cal}$ BP (Jalut et al. 1982). This was first characterised 
by the spread of Quercus and Corylus, while Pinus and Betula progressively declined due to a warmer and wetter climate. The spread of Abies started around $7,856 \pm 128 \mathrm{cal} \mathrm{BP}$, and its maximum peak is dated around $5,905 \pm 143 \mathrm{cal} \mathrm{BP}$, that is, later than in the Mediterranean Pyrenees but earlier than in the central and western parts of the range (Jalut et al. 1988; Cunill et al. 2015). The pollen study of the Etang de Lers lake sequence by Kenla and Jalut (1979) provides the first evidence of the decline of Abies caused by human activity. In the peat sequence of Bernadouze, this began at 4,331 \pm 347 cal BP.

In addition to the effects of human activity, the climate cooling recorded in western Europe from 5,000 cal BP has been interpreted as another major factor explaining the arrival of Fagus and reduction of Abies (Jalut et al. 1996; Magny et al. 2009). In the Bernadouze sequence, the arrival and spread of beech are dated around 4,547 \pm 219 cal BP and at Argentières (Aulus-les-Bains), located in a nearby valley, around 5,275 $\pm 152 \mathrm{cal} \mathrm{BP}$ (Fig. 1). But the time lag recorded from nearby valleys also implies that its expansion was strongly favoured by human practices. The development of woodland management and pasturing activities from the Bronze Age resulted in extensive clearance. Fagus, being capable of sprouting from stumps after coppicing and tolerant of pruning, was therefore favoured and developed to form mixed stands with Abies. From the medieval period, and especially from the Renaissance (ca AD 1470-1640), the intensification of charcoal burning for iron working led, in many parts of the eastern Pyrenees, to a gradual transformation from the Abies-Fagus mixed woods to Fagus-dominated ones (Davasse 2000).

\section{Materials and methods}

\section{Sampling strategy}

A multiple sampling strategy was used in order to obtain, first, an overall history of the woods surrounding the peat bog and, secondly, to determine the very local diversity in the main charcoal-making sectors (south, north and west), which are in currently wooded and pastoral areas (Fig. 1). A pedoanthracological sampling pit was excavated in the northern part (Berna 1, N 42 $48^{\prime} 13,172$ ' E $\left.1^{\circ} 25^{\prime} 27,253^{\prime \prime}\right)$, located in a soil sedimentary setting at $1,350 \mathrm{~m}$ on a sort of terrace beside the Bernadouze peat bog. Another pit was excavated near the western part 
of the peat bog in an open area (Berna 2, N 42 $\left.48^{\prime} 5,224^{\prime \prime} \mathrm{E} 1^{\circ} 25^{\prime} 36,526^{\prime \prime}\right)$, and a third one in the southern part (Berna 3, N 4248'13,536" E 1 ${ }^{\circ} 25^{\prime} 15,574$ '). In the woods and around the peat bog, archaeologists carried out a systematic field walking survey in five seasons of work, and used a soil auger to test all possible platforms that could have been used for building a charcoal kiln. The seven kiln terraces, the charcoal results from which have just recently been published (PySaragaglia et al 2018), are located in the three main areas of the pedoanthracological sampling pits (Fig. 1). Other charcoal kiln terraces have also been found closer to the three pits (Table 1). They are located between 70 and 155 $\mathrm{m}$ from Berna 1, 13- $24 \mathrm{~m}$ from Berna 2 and 52-264 $\mathrm{m}$ from Berna 3. The comparison of the charcoal spectra obtained from the soil pits with those from the charcoal kiln platforms allow us to discuss the degree of contamination of soils in the surroundings by charcoal from the kilns.

More precisely, Berna 2 is located at $1,390 \mathrm{~m}$, in an even aged stand of mature Fagus, at the top of a hillock which overlooks the upper part of the charcoal making area and below a rocky slope, a place where contamination of soils by charcoal from kilns may seem improbable. A $1.2 \mathrm{~m}$ pit was dug here into a classic brown forest soil, and as the deeper part was highly homogeneous, the bedrock was not reached (Fig. 3b).

Berna 3 is located at $1,400 \mathrm{~m}$, also in a tall Fagus woodland stage with abundant young growth in the understory. It is on a relatively steep gradient on the opposite side of the northernmost charcoal making area, beside an ancient track through the valley which is bordered by charcoal kiln terraces. At this site, soil contamination from the kilns is unpredictable, but we assume that it is unlikely or very limited in degree. The nearest charcoal kiln is located further down the slope below the pit at a distance of around $50 \mathrm{~m}$ from it (Fig. 1, Table 1). A $1 \mathrm{~m}$ pit was dug without reaching the bedrock. As at Berna 2, there is a brown forest soil in which the organic horizons extend down to a very fine mineral horizon but containing large blocks (Fig. 3c).

Berna 1 is located in a summer pasture at the foot of a small alluvial fan. We assumed that this site has recorded all fire events on the northern and northwestern slopes. A $1.2 \mathrm{~m}$ pit was dug, also without reaching the bedrock. The soil was quite similar to a sedimentary deposit, with an abrupt transition between the organic and mineral layer, and an organic part extending downwards (Fig. 3a). A 
major accumulation of charcoal was recorded at the transition from layer VII to VIII.

The soil profiles were subdivided into layers corresponding to distinct horizons seen during excavation and approximately $5-7 \mathrm{~kg}$ of soil was sampled from each one.

\section{Laboratory treatment and analysis}

After air drying, the samples were sieved to remove the coarse fraction of rock $>4$ $\mathrm{mm}$ and weighed for calculation of the anthracomass (charcoal content) (Talon et al. 1998; Touflan et al. 2010). The dried samples were wet sieved using a column of sieves with 4, 2 and $0.8 \mathrm{~mm}$ mesh sizes. Some clayey soil samples required immersion in a sodium hexametaphosphate $\left(\mathrm{Na}_{6} \mathrm{O}_{18} \mathrm{P}_{6}\right)$ solution before sieving. Charcoal was sorted from the dried material collected from the sieves under a binocular microscope. The amount of charcoal (anthracomass) was calculated on the basis of the weight of charcoal pieces larger than $0.8 \mathrm{~mm}$. The results are presented in terms of the total weight of charcoal per pit expressed in $\mathrm{mg}$ per $\mathrm{kg}$ of dry sediment (AP, anthracomass per pit), of charcoal per layer (AL, anthracomass per layer) and of charcoal per layer and per taxon (ALT, anthracomass per layer and taxon).

Fifty pieces of charcoal, if available, were randomly selected $(n=1,695)$ from each size fraction in the sieve from each layer (Robin and Nelle 2010; Feiss et al. 2017b). Robin et al. (personal communication, 2010) showed that this threshold of 50 charcoal pieces per size fraction was sufficient to determine the taxonomic diversity of the soil charcoal from each layer. When the number of charcoal pieces was lower, which was always the case for the $>4 \mathrm{~mm}$ size fraction, we did not complete it with more charcoal pieces from other mesh sizes so as not to risk under- or over-representation of the different taxa. In all sampled layers, charcoal fragments were more abundant in the $0.8 \mathrm{~mm}$ mesh fraction. Furthermore, we know that mechanical properties of charcoals from different woody taxa could influence the amount of fragmentation of the charred wood and its resistance to taphonomic processes (Chrzazvez et al. 2014). Although this still needs to be supported by experiments, Abies seems more subject to breakage than Fagus (PySaragaglia et al. 2017). Consequently, Fagus could be under-represented while Abies might be over-represented in the fraction from the $0.8 \mathrm{~mm}$ mesh, and 
similarly Abies could then be under-represented in the $2 \mathrm{~mm}$ fraction. Finally, in terms of the weight of charcoal expressed in mg per kg of sediment, an increase in the number of charcoal pieces per size fraction would distort the statistical data because the weight of 50 pieces of charcoal would probably be less than that of 70.

Taxonomic identification of charcoal was done using a Leica DM4 reflected light microscope with $100 \times, 200 \times, 500 \times$ and $1,000 \times$ objectives, a charcoal reference collection of Pyrenean trees, wood anatomy atlases (Schweingruber 1990; Vernet et al. 2001) and the charcoal reference collection of the GEODE laboratory (CNRS, University of Toulouse II Jean-Jaurès, France).

Charred fungal hyphae in the cells are regularly reported in pedoanthracological contexts, but they are not systematically quantified in published results. However, they may potentially supply essential information regarding the state of the wood (green, seasoned, healthy, dead, etc.) before carbonisation (Théry-Parisot 2001; Badal 2004; Carrión Marco 2005; Marguerie and Hunot 2007; Moskal-del Hoyo et al. 2010; Py-Saragaglia et al. 2015). In accordance with previous works, we defined presence of hyphae as follows; 0 , no hyphae in cells, 1 , presence with low occurrence in cells and 2, presence throughout with high occurrence (Fig. 4).

\section{Radiocarbon dating}

Ten charcoal pieces weighing more than $1 \mathrm{mg}$ were selected for dating, four from Berna 1, two from Berna 2 and four from Berna 3. In general, we selected charcoal from the main taxa represented in the pit and from layers with major changes in the dominant taxa (see results). Radiocarbon dating was done by accelerator mass spectrometry (AMS) in the Poznań Radiocarbon Laboratory (Poznań, Poland) and BETA Analytic laboratory (Miami, Florida, USA). Conventional ${ }^{14} \mathrm{C}$ ages were calibrated using OxCal v.4.2.4 (Bronk Ramsey and Lee 2013), based on the IntCal13.14c database (Reimer et al. 2013) and with a standard deviation of $2 \sigma$ (95\% probability). 


\section{Results}

\section{Pit contents}

Charcoal was found in all pits but not in all layers (Table 2, Fig. 5). The charcoal was present in varying amounts, with an AP per pit ranging from $1.5610^{3} \mathrm{mg} / \mathrm{kg}$ in Berna 2, $3.2110^{3} \mathrm{mg} / \mathrm{kg}$ in Berna 3, and $10.5910^{3} \mathrm{mg} / \mathrm{kg}$ in Berna 1, and the charcoal content by layer (AL) varied from less than $1 \mathrm{mg} / \mathrm{kg}$ in several layers of Berna 2 to a maximum of $4.9910^{3} \mathrm{mg} / \mathrm{kg}$ in Berna 1 (layer III). At every sampling point, the lowest amounts (AL) are from the deepest layers.

In Berna 1, the uppermost layers (II, III) have the highest AL values of 1.99 to $4.9910^{3} \mathrm{mg} / \mathrm{kg}$, and the deeper layers (VI, VIII, IX) the lowest AL values, 0.09 to $0.210^{3} \mathrm{mg} / \mathrm{kg}$. In Berna 2, the charcoal is concentrated in the two upper layers, with the highest $\mathrm{AL}$ in the first one, $1.3910^{3} \mathrm{mg} / \mathrm{kg}(\mathrm{I})$, but charcoal is absent between 30 and $90 \mathrm{~cm}$ depth. In Berna 3, charcoal is present in all layers, but the upper layers (I, II) have the highest AL values, 0.89 to $1.1610^{3} \mathrm{mg} / \mathrm{kg}$. The charcoal analysis of 1,695 fragments has enabled us to identify a total of 12 taxa: Abies, Abies/Juniperus, Juniperus, Taxus baccata, Pinus (sylvestris type), Fagus, Betula/Alnus, Alnus/Corylus, Fraxinus, Prunus, Angiosperm (indet.) and Gymnosperm (indet).

Abies corresponds to A. alba, the only species from this genus occurring in the French Pyrenees. Likewise, Fagus corresponds to F. sylvatica. The other taxa identified at genus level could correspond to several species. For example, Juniperus could correspond to J. communis ssp. communis and/or ssp. nana and/or J. sabina L. The taxon Pinus sylvestris type reflects an anatomical uncertainty between several species, and in this study, it could correspond to two, P. uncinata Ramond ex DC. and/or P. sylvestris L. The very small size of certain charcoal fragments combined with the poor preservation of anatomical features ruled out the identification of some genera from the same family such as Betula and Alnus, or from different families, Alnus and Corylus. This is also the case for some small charcoal pieces from Abies and Juniperus. If there are some robust anatomical criteria used to distinguish between taxa such as ray height, cell wall in ray or ray pits, these may not be visible when observing small twigs mainly 
composed of juvenile wood. Certain unidentifiable charcoal pieces are fragments of bark and pith.

Fagus was the most abundant taxon per layer, with the highest ALT in Berna 1 and the lowest in Berna 3. The highest Abies ALT was recorded in the shallowest layer of Berna 3, with $0.4610^{3} \mathrm{mg} / \mathrm{kg}$ and $0.2110^{3} \mathrm{mg} / \mathrm{kg}$ in layers I and II, respectively. Taxus was found in the three pits (Fig. 6). Its highest ALT was in Berna 3, with $0.4310^{3} \mathrm{mg} / \mathrm{kg}$ and $0.2110^{3} \mathrm{mg} / \mathrm{kg}$ in layers II and III, respectively. Berna 1 exhibits the highest number of taxa, while Berna 2 has the lowest. Berna 1 and 2 have closely related taxon composition patterns, with the deepest layer mainly composed of Abies and the shallowest dominated by Fagus. Berna 3 presents a different pattern, with all layers dominated by Taxus.

\section{Hyphal infestation evidence in wood charcoal cells}

Degree 1 of infestation, with a few hyphae present, is the commonest in the charcoal from the three pits and dominates all layers throughout the Berna 2 profile (Fig. 7). In Berna 1, degree 0, with no infestation, decreases from the deeper layer in which it dominates to the uppermost layer. Conversely, the NA degree (not assessed due to poor preservation) increases from the bottom to the top of the pits. Degree 2, with many hyphae present everywhere, was mainly found in Berna 1, with an equal proportion in all profiles. In Berna 3, the proportions of degrees 0,1 and NA are almost identical from the bottom of the profile to the top.

\section{Radiocarbon dates}

The ten radiocarbon dates ranged from the Middle to Late Bronze Age (M-LBA) to the beginning of the modern period (Table 3, Fig. 8). Five radiocarbon dates from Abies and Taxus charcoal from the three sampling points cover the end of the MBA and the LBA. Only one fragment of Fagus from Berna 1 (VII) is dated to late antiquity (AD 137-347, Table 3). Two fragments of Fagus and Abies from Berna 1 and 3, from the northern and north-western part of the peat bog periphery, are dated to the early medieval Carolingian period (AD 610-690). One fragment of Fagus from Berna 2 is dated to the high medieval period (1150-1250). Finally, one fragment of Fagus from Berna 1 is dated to between the end of the 15th century and the first half of the 17th century (AD 1470-1640). 


\section{Discussion}

\section{Methodological aspects}

\section{Relevance of applying pedoanthracology to an ancient charcoal making area}

The existence of another source of charcoal formation, such as charcoal making, in addition to that from forest fires, either natural or caused by humans, may have influenced the soil charcoal assemblages obtained from macroscopic charcoal particles, when they are counted, weighed and identified (Knapp et al. 2013). Charcoal particles from the kiln sites might have been transported over various distances by flowing water or soil erosion, and they might also have been incorporated into soils at different depths through processes of bioturbation or erosion. Knapp et al. (2013) have attempted to test the influence of nearby kiln sites on the soil charcoal content in the Harz mountains mining area, Germany. Results from this study showed 1, an increasing concentration of charcoal in deep soil horizons located at the bottoms of slopes resulting from the enrichment of these soils with charcoal from nearby kiln sites by a process of colluviation, and 2 , the great value of combining the two proxies, both natural and kiln charcoal, in order to obtain reliable information about local woodland structure and composition. The relevance of using charcoal from both sources has been also demonstrated by another study carried out on an ancient mining area, Argentières, Aulus-les-bains, in the French Pyrenees, not far from our study area (Fig. 1b; PySaragaglia et al. 2017). In this study, the small input of charcoal from kiln sites to soil charcoal found in pits is supported by their low charcoal content, close to that observed at the tree-line, and the proportions of main taxa that clearly differ between pedoanthracological pits and the nearest charcoal kilns.

In our study area, anthracomass values from the three pits, which vary from 1 to $10 \mathrm{~g} / \mathrm{kg}$ of sediment (Table 1), are comparable to those obtained from other sites across the Pyrenees at similar altitudes (Cunill et al. 2015; Danneyrolles et al. 2017), but are higher than those recorded from the nearby site of Argentières (PySaragaglia et al. 2017). As expected, the Berna 1 pit, located at the foot of a slope, has the highest anthracomass values (Fig. 5), which could result from local 
sources, and also from soil charcoal redeposited by colluviation from nearby slopes. Moreover, in contrast to Knapp et al. (2013), AL increases from the deepest to the uppermost layer (Fig. 5), as is commonly observed in results from high mountain areas (Carcaillet 1998; Talon 2010; Cunill et al. 2013, 2015). In comparison to the anthracological spectra from the nearest kilns which are mainly dominated by Abies and Fagus, there is a greater diversity of taxa in the charcoal assemblages from the three pits (Figs. 1, 5, Table 2). Moreover, certain taxa which are strongly represented in the pit charcoal assemblages, such as Taxus baccata, are almost unrepresented in kiln remains (Fig. 1). A greater similarity between the soil charcoal taxa was observed in the uppermost horizons (Figs. 1, 5), especially in Berna 1 (Fouédjeu 2016; Py-Saragaglia et al. 2018). Thus, we cannot totally exclude the possibility that part of the charcoal content of the pits may have been transported from nearby charcoal kiln sites by wind, water and also colluviation, and incorporated into the soils there, especially in the case of Berna 1. But for the two other pits (2 and 3), which lie above the kiln sites (Fig. 1c), we can assume a very small input of charcoal particles from the kilns into these soils. Large pieces of charcoal cannot be moved far by the wind, and most of the charcoal stays close to where it was formed, and is incorporated into the soil there (Gastaldo 1994).

The small input of charcoal from kilns into our soil sampling pits is also supported by the radiocarbon dates (Table 3), for which only those covering the medieval and modern periods could have come from a charcoal kiln. Finally, only one date from a Fagus charcoal fragment from Berna 1 corresponds to the peak of charcoal making activity in the 15 th-17th centuries.

These results confirm the relevance of a soil charcoal study carried out in a charcoal making area when the soil sampling point sites are carefully chosen, and they show that it is complementary to the charcoal analysis of kiln sites.

\section{Colluvial sediment input}

The absence of stratification in temperate climate soils is an important limitation to the interpretation of charcoal distribution (Carcaillet 2001). We also decided to study a soil sedimentary context (pit Berna 1) because this kind of site has shown its usefulness for reconstructing the chronology of past fire events (Knapp et al. 2013; Röpke and Krause 2013). Colluviation, the displacement of soil, may occur 
with erosive events. Soil materials may be removed from one place and then accumulated in another, here at the bottom of a slope. The layers deposited on top of each other in this way can form an interesting record of soil sedimentation, similar to a chrono-stratigraphy.

In a mountainous area, erosive events can be facilitated by human impact, especially the intensive use of fire for clearing in woods (Neuwinger 1970). The removal of trees favours the movement of soil down slopes by erosion under the influence of water or wind (Knapp et al. 2013). If clearing by fire causes or has contributed to erosion, a large amount of charcoal is also likely to be removed with the soil and when redeposited it may form charcoal layers (Röpke and Krause 2013). Thus, a great increase in the amount of charcoal at the bottom of a slope can represent a well-adapted proxy to study the history of burning practices. In Berna 1, the anthracomass peaks in layers VII, IV, II and II, compared to the layers directly above or below them, suggest the occurrence of four erosive events (Fig. 5). The radiocarbon dates make it possible to date two of these, the first between the Gallo-Roman period and late antiquity and the other during the Renaissance period (Table 3).

As expected, the distribution of the four radiocarbon dates within the Berna 1 soil profile is consistent with the distribution usually observed in a stratified context with a chronological organisation pattern (Table 3). Additional dates would be needed to support this conclusion, so we will use this result with caution.

\section{Patterns of change in the composition and structure of the woodlands at forêt de Bernadouze from the LBA onwards}

The results from the soil charcoal analysis have provided new insights on the patterns of change in the composition and structure of forêt de Bernadouze from the Bronze Age, and so well before the presumed start of charcoal making there. Our results are consistent with the state of knowledge at the regional level (Jalut et al. 1982; see Patterns of change in the Holocene vegetation highlighted by previous palaeoecological studies) by demonstrating at a very high spatial resolution the changes in the vegetation in the forêt de Bernadouze.

In the area discussed, soil charcoal analysis shows that the woodland has always been mainly composed of Abies associated with Taxus between the end of the MBA and the LBA (Fig. 5, Table 2). During this period, Fagus was probably 
present, but it remained scarce until the first centuries AD. The association of these three trees which are tolerant of shade, at least during the juvenile stage, is quite similar to the range of taxa currently observed in natural Abies-(Fagus) woods growing in the Carpathian Mountains and on the northern slopes of the eastern Pyrenees, but in which Taxus is scarce (Larrieu and Cabanettes 2012). Taxus charcoal was present in all the pits, but mainly in Berna 3, from within the northwestern part of the wood and above the peat bog (Figs. 1c, 5). Yew, an evergreen non-resinous gymnosperm tree is a European native species, with an ecological niche restricted to regions with mild winters and high rainfall, but it is well adapted to a range of edaphic conditions (Thomas and Polwart 2003; Casals et al. 2015). Leuthold (1998) highlighted its particular role as an "intermediate triple species", as 1, in ecological succession, Taxus tends to settle between pioneer and climax taxa; 2 , in its place in vegetational communities, Taxus occupies mostly a co-dominant role in the lower tree canopy such as halfway between the overstory and the understory, and 3, regarding its morphology, Taxus is intermediate between broadleaved trees and conifers. Moreover, the study of Piovesan et al. (2009) from the Apennine area in Italy showed the correlation between occurrence of Taxus and continuous areas of woodlands. They also considered Taxus to be an indicator of both a healthy woodland ecosystem (Piovesan et al. 2009) and, regarding its role as a "triple intermediate species", a component of a complex woodland ecosystem that might be ancient.

The high degree of hyphal infestation observed in the charcoal from all pits could show the burning of dead wood, either from standing trees or on the ground and/or ageing mature trees several centuries old (Fig. 7). Several studies have already demonstrated the strong link between woodland stand maturity and the occurrence of saproxylic fungi (Christensen et al. 2005; Larrieu and Gonin 2008), which are dependent for their growth on the continuity of availability of dead and weakened wood, such as on old trees. The evidence of these fungi, as hyphae preserved in soil charcoal, therefore confirms the past presence of a mature tree stand rich in dead wood. An ongoing project carried out in the GEODE laboratory should clarify the relationship between the levels of hyphal infestation in charcoal cells and the state of the wood before carbonisation, by using experiments to make modern examples for comparison. All of these indicators show that the forêt de Bernadouze has been composed of a very diverse range of trees, probably in 
various woodland types and at different stages of maturity, from the LBA up to the start of the Middle Ages.

In Berna 1, the first occurrence of Fagus is in layer VII and dated between the Gallo-Roman period and late antiquity (Fig. 5, Table 3). From this period onwards, the results from Berna 1 show an increase of Fagus and decrease of both Abies and Taxus (Fig. 5). In Berna 2, the first record of Fagus is dated to the high medieval period and in Berna 3 to the Carolingian period (Table 3). The first major change in woodland composition, characterised by the appearance of Fagus, is also recorded at least between the Gallo-Roman period and late antiquity. It is difficult to make assumptions about its appearance, but we assume the maintenance of a wooded environment, more or less continuous, with open glades. That is supported by the absence of a heathland or scrub phase that would have been marked by high occurrences of Juniperus and other light-demanding taxa.

Layer IV of Berna 1 marked a major change, with the total disappearance of Taxus (Fig. 5). This layer is also characterised by the likelihood of an erosive event, the most taxa that are indicators of woodland opening and the strong decline of Abies. All these elements suggest the phases of canopy opening, which were very unfavourable to Taxus and Abies. From this period, the main structure and composition of the forêt de Bernadouze were established, and they have been maintained up to the present time by new phases of opening up of the woodland environment, as indicated by several erosive events shown by charcoal peaks (Berna 1 layers III and II, Fig. 5). The woodland features are therefore the same as those evidenced by the analysis of material from charcoal kilns (Py-Saragaglia et al. 2018) and as reported by historical documents, a beechwood with some fir.

\section{Late Holocene fire history and human activities in the forêt de Bernadouze}

Charcoal fragments in soils result from the occurrence of at least one fire event, which could correspond to one or more fires within a short period that occurred in the surroundings of the study area (Higuera et al. 2008; Bal et al. 2011). The origin of a fire (or fire event) could be either natural or human. It is always difficult, if not impossible, to attribute with certainty a natural or human cause to a fire event identified from the charcoal of a particular date. When there are very 
different and widely separated radiocarbon dates in a soil record, such as Bronze Age and medieval period, we can reasonably conclude that we have different fire events. However, the obtained radiocarbon dates, from a fragment of tree rings constituting the charcoal, may relate to the death of the dated tree. If the dated part of it included its bark or outer tree rings, and if the death of the tree was related to the fire event, in this case only would the charcoal provide the date of the fire event itself. In other cases, the date would represent the age of that part of the tree from which the charcoal came, which might be earlier than the date of the fire in which its charcoal was formed, if the tree had lain dead for some time. Moreover, given the uncertainty within the ranges of radiocarbon dates, it is clearly impossible to date precisely a fire event with charcoal from soils, unless we can date twigs or ring fragments with bark. That is why it can be useful to compare these data with other results from the area, the wider region or even beyond it (Vannière et al. 2001; Galop et al. 2003, 2013; Rius et al. 2009, 2012; Bal et al. 2011; Fouédjeu 2016; Py-Saragaglia et al. 2018). In the Pyrenees, studies have shown that Holocene fire history may be divided into two main phases. The first was from the early Holocene to 3,000 cal BP during which the fire regime was mainly controlled by the climate, and the second was from 3,000 cal BP to the current period, when fires were mainly caused by human practices (Bal et al. 2011; Rius et al. 2012; Cunill et al. 2013). Fire played an important role in past Pyrenean land use and the formation of cultural landscapes there (Galop et al. 2003), and it is still used for highland pasture management there by prescribed burnings now (Métailié 1981, 2006; Girona-Garcia et al. 2017).

The ten radiocarbon dates on charcoal fragments range from 3,250-3,067 to 480$310 \mathrm{cal}$ BP (Fig. 8, Table 3). Nine of these dates are within the phase of fires connected with humans, described by several authors (Galop et al. 2003; Riera et al. 2004; Guiter et al. 2005; Rius et al. 2009; Bal et al. 2011; Pèlachs et al. 2011). The only date from a different phase corresponds to the MBA and the period just after the climatic deterioration, when the colder and wetter conditions between 1900 and $1400 \mathrm{cal}$ BC would have reduced the likelihood of fire (Tinner et al. 2003; Galop et al. 2007). Although we cannot totally rule out the possibility that the charcoal reported here might also be of natural origin, we assume that it derives from human actions, because it is similar in date to such fires recorded in this region and throughout the Pyrenees by previous studies. 
Abies and Taxus give the oldest dates, while Fagus is generally more recent, as already reported from another beechwood in the eastern Pyrenees (Danneyrolles et al. 2017). In our study, the five radiocarbon dates on Abies and Taxus charcoal from the deepest layers of the three pits correspond to the Bronze Age and more precisely to the end of the MBA and the LBA (Fig. 5, Table 3). This period is also characterised by an increase of pollen indicators indicative of human activity and a decrease of tree pollen in the peat bog sequence of Bernadouze (Jalut et al. 1982). The main explanation, also seen in different places across the Pyrenees, is a change from a system of woodland use when trees were abundant to one of wood pasture and farming associated with clearance of woodland by burning around 2000 cal BC (Carozza et al. 2005; Rius et al. 2009, 2012; Galop et al. 2013). This change may have led to the expansion of cultivated areas thus causing an increase of pollen indicators of arable and pastoral land (Galop et al. 2003; Rius et al. 2012). In the forêt de Bernadouze, however, our results did not show signs of significant agriculture other than pastoralism. Regarding the data from Berna 1, the oldest charcoal dates (M-LBA) are mainly from primary woodland with Abies and Taxus, then from the Gallo-Roman period or late antiquity our results show the presence of Fagus (Table 3). These results allow us to suggest the introduction of a woodland pasture management system following initial tree clearance by slash and burn. In this context, we propose two possible explanations for the use of fire, 1, to create pastures instead of woodlands, and/or 2, to keep the tree stands open as wood pasture to promote the development of shrubs and herbaceous undergrowth favourable to livestock.

Dates of Carolingian age obtained on three pieces of Fagus and Abies charcoal from Berna 3 and Berna 2 respectively, located in the north-eastern and northwestern parts of the forêt de Freychinède, might reflect the spread of intermediate pastures and/or hay meadows into former woodland areas (Table 3).

The second Fagus charcoal fragment, dated to the Renaissance period (14th-17th century), has been chosen because it comes from the level that marks a transition between the deeper levels dominated by Abies and those above which are dominated by Fagus (Fig. 5, Table 3). This level is assumed to mark the beginning of real woodland management with local uses that favoured Fagus. As shown by another study (Py-Saragaglia et al. 2018), our data suggest that human practices have been the main driver of the development of Fagus woodland in the 
forêt de Bernadouze. The Renaissance period is well-known to have been a time of much charcoal making in the Bernadouze catchment area, when mouline technology, a sort of hydraulic forge combining direct reduction processes, developed in Vicdessos (Verna 2001; Fouédjeu 2016).

Finally, we can note that in this particular area, no soil charcoal had a date later than the Renaissance, which was the time when charcoal making developed intensively. That could support the idea that the forêt de Bernadouze was devoted exclusively to charcoal production from the late medieval period to the17th c, implying that no new woodland areas were cleared by using fire. To satisfy the great requirements for wood, the woodland became one purely with beech, as reported by historical texts and maps.

\section{Was the extinction of Taxus in the forêt de Bernadouze caused by humans?}

The evidence of Taxus in the forêt de Bernadouze during the Bronze Age is one major result from this study, since it has not been detected by other palaeoecological or ethnobotanical studies in this valley, except a few charcoal fragments found in kilns 6 and 79 (Fig. 1c). In the eastern Pyrenees, as in other Mediterranean areas, yew usually grows in isolated populations in shady mountain ravines and on cliffs, or as a sub-canopy tree in a variety of woodland communities (Piovesan et al. 2009). Currently, in the vicinity of our study area, stunted and twisted yews occasionally occur on steep slopes, at the base of rocky spurs or below glaciated valleys at around 1,500-1,600 m, such as below the Bassiès ponds (Fig. 1). Taxus occurs mostly as a shrub or as a tree with several trunks and with a spreading, rounded or pyramidal canopy (Thomas and Polwart 2003; Piovesan et al. 2009). It is dioecious, with both male and female trees, which is very rare in gymnosperms (Martin and Thiébault 2010). This long-lived and shade tolerant tree is very vulnerable to disturbances such as fire and to climatic extremes of temperatures or drought (Thomas and Polwart 2003). In Berna 3, Taxus is the main taxon in charcoal identified throughout the profile, and radiocarbon dates show its presence during the Bronze Age (Fig. 5, Table 3). It has been identified occasionally in Berna 1 and 2. In Berna 1, Taxus was identified from layer IX to layer IV (Fig. 5). The radiocarbon date on Taxus from layer VIII of Berna 1 is the oldest record found. Layer III marks the end of Taxus 
records in Berna 1. The radiocarbon dates are consistent with each other and show clearly that Taxus occupied a prominent place in the forêt de Bernadouze between at least the Bronze Age and the Carolingian period (Table 3).

Several reviews have covered the place of Taxus in past and current vegetation and its uses by past societies in southwestern Europe (Pérez-Díaz et al. 2013; Uzquiano et al. 2015), the Alps (Martin and Thiébault 2010) and in Belgium (Deforce and Bastiaens 2007). These studies mainly showed the lack of knowledge about yew and the possible causes of its scarcity, and they assume that its range of distribution was more extensive in the past. Some pollen data from the eastern Pyrenees show that Taxus spread there between the Atlantic and Subboreal periods (Reille and Lowe 1993) and it then spread and increased together with the development of deciduous woods. Its decline started with the decline of mesophilous trees and the spread of Abies, until it disappeared with the arrival and spread of Fagus (Reille and Lowe 1993).

Climatic conditions as well as successive climate changes throughout the Holocene are often the hypotheses put forward to explain the disappearance of Taxus (Deforce and Bastiaens 2007; Uzquiano et al. 2015). However, several ethnobotanical studies have indicated the complex relationship between humans and Taxus, and have suggested a most probable human cause to explain its disappearance (Uzquiano et al. 2015). Despite the high quality of its timber, with good mechanical resistance and flexibility, and used in the past for making tools and weapons, it is feared by humans. The high toxicity of different parts of the plant (leaves, seeds and wood) from taxoids with cardiotoxic properties has always led it to be regarded as the main cause of the poisoning of cattle by plants (Isler et al. 2007; Uzquiano et al. 2015). Ingested quantities of the order of $500 \mathrm{~g}$ may be sufficient to cause rapid death in cattle. Moreover, the increased demand for its timber may have led to habitat fragmentation that may have affected its pollination and viability. The production of viable seeds requires the presence of trees of both sexes together. Finally, Taxus, given its slow growth rate, is unable to compete with other trees with good colonizing ability such as Fagus, which grows more quickly. Taxus ended up by becoming part of the woodland understory (Abellà 2009; Uzquiano et al. 2015). Currently, the Mediterranean Taxus habitat is recognized as a priority for biodiversity conservation within the European Union (European Commission 1992). 
Our results suggest that the progressive decline of Taxus in the forêt de Bernadouze from late antiquity in the 5th century AD until its disappearance, probably in the 7th-9th century, in the Carolingian period, is likely to have been caused by human pressure. We therefore consider it important to improve our knowledge of the geographical range of yew and its role in woodland communities in the past. Owing to climate change and changing human practices, there is an urgent need to clarify the potential ecological niche for such woodland taxa so that future vegetation changes can be anticipated.

\section{Conclusions}

This study carried out in the forêt de Bernadouze supports the relevance of using soil charcoal results to study the relationships between humans and woodland ecosystems in an ancient charcoal making area with very high spatial and temporal resolution. The information provided by soil charcoal analysis has been compared with the data provided by regional palaeoecological, archaeological and historical studies. The use of a soil sedimentary record has helped to interpret the chronological changes in vegetation and practices. Although our data do not include the first part of the Holocene, the Neolithic or Early Bronze Age, they do allow us to discuss the patterns of change in tree diversity and maturity in the forêt de Bernadouze from the Bronze Age, as well as the main causes of change. The main results show the ancient character of the forêt de Bernadouze, at least from the LBA, despite the development of pressure from humans. From this period until the Carolingian period, our results suggest that the woodland was characterised by a high degree of maturity of the trees, biodiversity and complexity. Nevertheless, our results also indicate that fire was a key element of woodland management from the MBA to the late medieval period. The progression towards a woodland pasture management system led to a transformation in terms of composition and structures of the woodland. From the Bronze Age, our results suggest that the composition and functioning of the wood must have been very close to those currently observed in semi-natural fir and beech woods. Here, Abies and Taxus were the main trees in woodland which contained some old trees as well as dead wood, as shown by the degree of infestation with fungal hyphae. The intensification of wood pasturing is supported by the arrival and spread of Fagus from the Gallo-Roman period to late antiquity. 
Then, the transition from an Abies dominated woodland to one with mainly Fagus is well recorded in Berna 1 and dated to the Renaissance period. This change involves the beginning of 1, the decrease in Abies and the disappearance of Taxus, as well as 2, the higher occurrence of taxa indicative of openings in the woodland. The transition to a multifunctional managed woodland, coinciding with the beginning of the iron industry, probably developed and continued until the expansion of charcoal production from the beginning of the Renaissance period, around (AD 1500).

Finally, one of the main results from this study is the identification of Taxus as a major woodland tree from the Bronze Age probably until the Carolingian period. Its decline at least from late antiquity has probably been the result of human action. We could assume that the composition and functioning of the current Fagus-dominated woodland reflects several millennia of human uses and management. However, all the evidence supports the hypothesis of 1, a tree cover, more or less sparse, that has been maintained from the LBA, despite the development of pasturing, and 2, the ancient character of the forêt de Bernadouze, which seems have been maintained as a managed woodland at least from the late medieval period.

Acknowledgements This research was carried out within the projects CHARINTERBERNADOUZE post-doctoral project (2016-2017) and FODYNA, led by Vanessa PySaragaglia, which have provided financial and technical support for field investigations and radiocarbon dating. This work is part of the OHM-Haut Vicdessos interdisciplinary program headed by D. Galop, and was funded by the Labex DRIIHM, French programme "Investissements d'Avenir" (ANR-11-LABX-0010), which is managed by the ANR. The TAXUS project, funded by the laboratory GEODE (exploratory project) and led by the authors, has supported part of the radiocarbon analyses. The authors would like to thank Laure Gandois for her help during the fieldwork and her contribution to a better understanding of the soil conditions within the forest. The help of Stéphane Binet should also be acknowledged for his contribution related to the specific weather prevalent in our study area, and that of Hugues Barcet for GIS mapping and field assistance. We would also like to thank the reviewers of this article whose comments helped us to improve it.

\section{References}

Abellà I (2009) Cultura del Tejo, la esplendor y decadencia de un patrimonio vital (Patrimonio Vivo).

Editorial de Urueña SL, Valladolid 
Badal E (2004) Análisis antracológico de los restos del fuego doméstico del abrigo de los Baños (Ariño, Teruel). In: Utrilla P, Rodanés JM (eds) Un asentamiento epipaleolítico en el valle del Río Martín. El Abrigo de los Baños (Ariño, Teruel), (Monografías Arqueológicas 39) Universidad de Zaragoza, Zaragoza, pp 63-74 Bal MC, Harfouche R, Poupet P, Campmajo P, Rendu C (2008) Archaeo-environmental studies of cultivation terraces in the Enveig Mountain (Cerdagne) in Eastern Pyrenees (France). Use of pedo-anthracology. In: Fiorentino G, Magri D (eds) Charcoals from the Past: cultural and palaeoenvironmental implications: proceedings of the Third International Meeting of Anthracology, CavallinoJune, Lecce (Italy), June 28th-July 1st 2004. BAR International Series 1807. Archaeopress, Oxford, pp 11-23

Bal MC, Pelachs A, Perez-Obiol R, Julia R, Cunill R (2011) Fire history and human activities during the last 3300 cal yr BP in Spain's Central Pyrenees: The case of the Estany de Burg. Palaeogeogr Palaeoclimatol Palaeoecol 300:179-190

Bronk Ramsey C, Lee S (2013) Recent and planned developments of the program OxCal. Radiocarbon 55:720-730

Camarero L, Masqué P, Devos W et al (1998) Historical variations in lead fluxes in the Pyrenees (Northeast Spain) from a dated lake sediment core. Water Air Soil Pollut 105:439-449

Carcaillet C (1998) A spatially precise study of Holocene fire history, climate and human impact within the Maurienne valley, North French Alps. J Ecol 86:384-396

Carcaillet C (2001) Are Holocene wood-charcoal fragments stratified in alpine and subalpine soils? Evidence from the Alps based on AMS 14C dates. Holocene 11:231-242

Carrión Marco Y (2005) La vegetación mediterránea y atlántica de la Península Ibérica: nuevas secuencias antracológicas. (Serie de Trabajos Varios 104) Diputación Provincial de Valencia, Valencia

Carozza L, Galop D, Marembert F, Monna F (2005) Quel statut pour les espaces de montagne durant l'âge du Bronze? Regards croisés sur les approches société-environnement dans les Pyrénées occidentales. Doc d'Archéol Méridionale 28:34-45

Casals P, Camprodon J, Caritat A et al (2015) Forest structure of Mediterranean yew (Taxus baccata L.) populations and neighbor effects on juvenile yew performance in the NE Iberian Peninsula. Forest Systems 24:1-9

Christensen M, Heilmann-Clausen J, Walleyn R et al (2005) Wood-inhabiting fungi as indicators of nature value in European beech forests. In: Marchetti M (ed) Monitoring and indicators of forest biodiversity in Europe - from ideas to operationality. (EFI Proceedings 51) European Forest Institute, Joensuu, pp 229-237

Chrzazvez J, Théry-Parisot I, Fiorucci G et al B (2014) Impact of post-depositional processes on charcoal fragmentation and archaeobotanical implications: experimental approach combining charcoal analysis and biomechanics. J Archaeol Sci 44:30-42

Cunill R, Soriano JM, Bal MC et al (2012) Holocene treeline changes on the south slope of the Pyrenees: a pedoanthracological analysis. Veget Hist Archaeobot 21:373-384

Cunill R, Soriano JM, Bal MC et al (2013) Holocene high-altitude vegetation dynamics in the Pyrenees: a pedoanthracology contribution to an interdisciplinary approach. Quat Int 289:60-70

Cunill R, Métailié JP, Galop D et al (2015) Palaeoecological study of Pyrenean lowland fir forests: Exploring mid-late Holocene history of Abies alba in Montbrun (Ariège, France). Quat Int 366:37-50 
Danneyrolles V, Saulnier M, Talon B et al (2017) Analyse pédoanthracologique. Travaux de la Massane, Tome ${ }^{\circ} 111$

Davasse B (2000) Forêts, charbonniers et paysans dans les Pyrénées de l'Est, du moyen-âge à nos jours. Une approche géographique de l'histoire de l'environnement. GEODE, Toulouse

Deforce K, Bastiaens J (2007) The Holocene history of Taxus baccata (yew) in Belgium and neighbouring regions. Belg J Bot 140:222-237

De Froidour L (1669) Archives départementales de l'Ariège -ADA-, 2B31, fo83-89 and fo237-238

Dralet (1807) Archives départementales de la Haute-Garonne -ADH-, série P 334

Dubois C, Métailié J-P (2001) Anthropisation et dynamique forestière dans les Pyrénées ariégeoises à l'époque gallo-romaine. L'exemple de la forêt de Lercoul. In: Sablayrolles B (ed) Les ressources naturelles des Pyrénées, leur exploitation durant l'Antiquité. (Entretiens d'archéologie et d'histoire 6) Musée départemental, Saint-Bertrand-de-Comminges, pp 8-19

Ejarque A, Miras Y, Riera S et al (2010) Testing micro-regional variability in the Holocene shaping of high mountain cultural landscapes: a palaeoenvironmental case-study in the eastern Pyrenees. J Archaeol Sci $37: 1,468-1,479$

European Commission (1992) Habitat 9580*, European Council Directive 43/92/EEC

Feiss T, Horen H, Brasseur B et al (2017a) Historical ecology of lowland forests: Does pedoanthracology support historical and archaeological data? Quat Int 457:99-112

Feiss T, Horen H, Brasseur B et al (2017b) Optimal sampling design and minimal effort for soil charcoal analyses considering the soil type and forest history. Veget Hist Archaeobot 26:627-637

Fouédjeu L (2016) Histoire des forêts et du charbonnage dans les Pyrénées ariégeoises : analyses anthracologiques et dendro-anthracologiques des plateformes de charbonnage de la forêt de Bernadouze (Sucet-Sentenac). Rapport de master 2 Géoarchéologie-Bioarchéologie, Montpellier

Galop D (1998) La forêt, l'homme et le troupeau dans les Pyrénées : 6000 ans d'histoire de l'environnement entre Garonne et Méditerranée: contribution palynologique. GEODE, Toulouse

Galop D, Jalut G (1994) Differential human impact and vegetation history in two adjacent Pyrenean valleys in the Ariège basin, southern France, from 3000 B.P. to the present. Veget Hist Archaeobot 3:225-244

Galop D, Tual M, Monna F, Dominik J, Beyrie A, Marembert F (2001) Cinq millénaires de métallurgie en montagne basque. Les apports d'une démarche intégrée alliant palynologie et géochimie isotopique du plomb. Sud-Ouest Européen 11:3-15

Galop D, Mazier F, Lopez-Saez JA, Vanniere B (2003) Palynologie et histoire des activités humaines en milieu montagnard. Bilan provisoire des recherches et nouvelles orientations méthodologiques sur le versant nord des Pyrénées. Archéologie du midi médiéval 21:159-170

Galop D, Carozza L, Marembert F, Bal MC (2007) Activités pastorales et climat durant l'âge du Bronze dans les Pyrénées : l'état de la question à la lumière des données environnementales et archéologiques. In: Richard H, Magny M, Mordant C (eds) Environnements et cultures à l'âge du Bronze en Europe occidentale.

(Documents préhistoriques 21) Editions du CTHS, Paris, pp 107-119

Galop D, Rius D, Cugny C, Mazier F (2013) A history of long-term human-environment interactions in the French Pyrenees inferred from the pollen data. In: Lozny L (ed) Continuity and change in cultural adaptation 
to mountain environments. From prehistory to contemporary threats. (Studies in Human Ecology and Adaptation 7) Springer, New York, pp 19-30

Garcés-Pastor S, Cañellas-Boltà N, Pèlachs A et al (2017) Environmental history and vegetation dynamics in response to climate variations and human pressure during the Holocene in Bassa Nera, Central Pyrenees. Palaeogeogr Palaeoclimatol Palaeoecol 479:48-60

Gastaldo RA (1994) The genesis and sedimentation of phytoclasts with examples from coastal environments. In: Traverse A (ed) Sedimentation of organic particles. Cambridge University Press, Cambridge, pp 103-128

Girona-García A, Badía-Villas D, Martí-Dalmau C et al (2017) Effects of prescribed fire for pasture management on soil organic matter and biological properties: A 1-year study case in the Central Pyrenees. Sci Total Environ 618:1,079-1,087

González-Sampériz P, Aranbarri J, Pérez-Sanz A et al (2017) Environmental and climate change in the southern Central Pyrenees since the Last Glacial Maximum: A view from the lake records. Catena 149:668688

Guiter F, Andrieu-Ponel V, Digerfeldt G et al (2005) Vegetation history and lake-level changes from the Younger Dryas to the present in Eastern Pyrenees (France): pollen, plant macrofossils and lithostratigraphy from Lake Racou (2000 m a.s.1.). Veget Hist Archaeobot 14:99-118

Higuera PE, Brubaker LB, Anderson PM et al (2008) Frequent fires in ancient shrub tundra: implications of paleorecords for arctic environmental change. PLoS ONE 3:e1744

Isler C, Pineau X, Alves de Oliveira L (2007) Intoxication à l'if dans un élevage bovin. Bulletin des GTV 39:73-76

Jalut G (1984) L'action de l'homme sur la forêt montagnarde dans les Pyrénées ariègeoises et orientales depuis 4000 BP d'après l'analyse pollinique. In: Actes du 106e Congrès National des sociétés savantes, Section de Géographie, Perpignan 1981. Ministère de l'Education Nationale Comité des Travaux Historiques et Scientifiques, Paris, pp 163-172

Jalut G, Delibrias G, Dagnac J, Mardones M, Bouhours M (1982) A palaeoecological approach to the last 21 000 years in the Pyrenees: the peat bog of Freychinède (alt. 1350 m, Ariège, South France). Palaeogeogr Palaeoclimatol Palaeoecol 40:321-336, 343-359

Jalut G, Andrieu V, Delibrias G, Fontugne M, Pagès P (1988) Paleoenvironment of the valley of Ossau (western French Pyrenees) during the last 27000 years. Pollen Spores 30:357-394

Jalut G, Marti JM, Fontugne M, Delibrias G, Vilaplana JM, Julia R (1992) Glacial to interglacial vegetation changes in the northern and southern Pyrenees: deglaciation, vegetation cover and chronology. Quat Sci Rev $11: 449-480$

Jalut G, Aubert S, Galop D, Fontugne M, Belet JM (1996) Type regions F-zg and F-r, the northern slope of the Pyrenees. In: Berglund BE, Birks HJB, Ralska-Jaziewczowa M, Wright HE (eds) Palaeoecological events during the last 15000 years: Regional syntheses of palaeoecological studies of lakes and mires in Europe. Wiley, Chichester, pp 612-632

Jalut G, Galop D, Belet JM et al (1998) Histoire des forêts du versant nord des Pyrénées au cours des 30000 dernières années. J Bot Soc Bot Fr 5:73-84

Kenla J (1977) Analyse pollinique des sédiments post-glaciaires de l'étang de l'Hers. (1274 m, Ariège).

Thèse de doctorat, Université Pierre Sabatier, Toulouse 
Kenla JV, Jalut G (1979) Déterminisme anthropique du développement du hêtre dans la sapinière du Couserans (Pyrénées ariègeoises, France) durant le Subatlantique. Geobios 12:735-738

Knapp H, Robin V, Kirleis W et al (2013) Woodland history in the upper Harz Mountains revealed by kiln site, soil sediment and peat charcoal analyses. Quat Int 289:88-100

Larrieu L, Gonin P (2008) L'indice de Biodiversité Potentielle (IBP): une méthode simple et rapide pour évaluer la biodiversité potentielle des peuplements forestiers. Rev For Fr 6:727-748

Larrieu L, Cabanettes A (2012) Species, live status, and diameter are important tree features for diversity and abundance of tree microhabitats in subnatural montane beech-fir forests. Can J For Res 42:1,433-1,445

Leuthold C (1998) Die pflanzensoziologische und ökologische Stellung der Eibe (Taxus baccata L.) in der Schweiz - ein Beitrag zur Wesenscharakterisierung des „Ur-Baumes“ Europas. Schweiz Z Forstwes 49:349371

Magny M, Peyron O, Gauthier E et al (2009) Quantitative reconstruction of climatic variations during the Bronze Age based on pollen and lake-level data in the NW Alps, France. Quat Int 200:102-110

Marguerie D, Hunot JY (2007) Charcoal analysis and dendrology: data from archaeological sites in northwestern France. J Archaeol Sci 34:1,417-1,433

Martin L, Thiébault S (2010) L'if (Taxus baccata L.): histoire et usage d'un arbre durant la Préhistoire récente. L'exemple du domaine alpin et circum-alpin. In: Delhon C, Théry-Parisot S, Thiébault S (eds) Des hommes et de plantes. Exploitation du milieu et gestion des ressources végétales de la Préhistoire à nos jours. Anthropobotanica 2010.1.4. Éditiones APDCA, Antibes, pp 3-20

Métailié JP (1981) Le feu pastoral dans les Pyrénées centrales: (Barousse, Oueil, Larboust). CNRS, Paris Métailié JP (2006) Mountain landscape, pastoral management and traditional practices in the northern Pyrenees (France). In: Agnoletti M (ed) The conservation of cultural landscapes. CABI, Wallingford, pp 108123

Moskal-del Hoyo M, Wachowiak M, Blanchette RA (2010) Preservation of fungi in archaeological charcoal. J Archaeol Sci 37:2,106-2,116

Neuwinger I (1970) Böden der subalpinen und alpinen Stufe in den Tiroler Alpen. Mittl Ostalp-din Ges Vegetkde 11:135-150

Pèlachs A, Julià R, Pérez-Obiol R et al (2011) Potential influence of bond events on mid-Holocene climate and vegetation in southern Pyrenees as assessed from Burg lake LOI and pollen records. Holocene 21:95-104 Pérez-Díaz S, López-Sáez JA, Ruiz-Alonso M et al (2013) Holocene history of Taxus baccata in the Basque Mountains (Northern Iberian Peninsula). Lazaroa 34:29-41

Piovesan G, Saba EP, Biondi F et al (2009) Population ecology of yew (Taxus baccata L.) in the Central Apennines: spatial patterns and their relevance for conservation strategies. Plant Ecol 205:23-46 Py-Saragaglia V, Durand A, Ancel B et al (2015). Les dynamiques de la végétation et des anthroposystèmes d'altitude cernées par l'anthracologie pastorale et minière à l'échelle d'un haut vallon alpestre (Freissinières, France). ArchéoSciences, Revue d'archéométrie 39:69-92

Py-Saragaglia V, Cunill Artigas R, Métailié JP et al (2017) Late Holocene history of woodland dynamics and wood use in an ancient mining area of the Pyrenees (Ariège, France). Quat Int 458:141-157 
Py-Saragaglia V, Saulnier M, Cunill Artigas R et al (2018) Long-term forest evolution and woodland uses in an ancient charcoal-production forest of the French eastern Pyrenees: an interdisciplinary approach with high spatio-temporal resolution. In: Paradis-Grenouillet S, Aspe C, Burri S (eds) Into the woods, overlapping perspectives on the history of ancient forests. Éditions Quae, Versailles, pp 441-519

Reille M (1993) New pollen analytical researches at Freychinède, Ariège, Pyrenees, France. Diss Bot 196:377-386

Reille M, Lowe JJ (1993) A re-evaluation of the vegetation history of the eastern Pyrenees (France) from the end of the last glacial to the present. Quat Sci Rev 12:47-77

Reimer PJ, Barad E, Baykuss A et al (2013) IntCal13 and Marine13 radiocarbon age calibration curves 050,000 years cal BP. Radiocarbon 55:1,869-1,887

Riera S, Wansard G, Julià R (2004) 2000-year environmental history of a karstic lake in the Mediterranean Pre-Pyrenees: the Estanya lakes (Spain). Catena 55:293-324

Rius D, Vanniere B, Galop D (2009) Fire frequency and landscape management in the north-western Pyrenean piedmont (France) since the early Neolithic (8000 cal. BP). Holocene 19:847-859

Rius D, Vannière B, Galop D (2012) Holocene history of fire, vegetation and land use from the Central Pyrenees (France). Quat Res 77:54-64

Robin V, Nelle O (2010) Charcoal taxonomical assemblages: is it possible to definite threshold of identification. First international workshop in Pedoanthracology, Aix en Provence, June 2010. Unpublished Oral communication

Röpke A, Krause R (2013) High montane-subalpine soils in the Montafon Valley (Austria, Northern Alps) and their link to land-use, fire and settlement history. Quat Int 308:178-189

Saulnier M, Talon B, Edouard JL (2015) New pedoanthracological data for the long-term history of forest species at mid-high altitudes in the Queyras Valley (Inner Alps). Quat Int 366:15-24

Schweingruber FH (1990) Anatomy of European woods. An atlas for the identification of European trees, shrubs and dwarf shrubs. Haupt, Bern

Talon B (2010) Reconstruction of Holocene high-altitude vegetation cover in the French Southern Alps: evidence from soil charcoal. Holocene 20:34-44

Talon B, Carcaillet C, Thinon M (1998). Etudes pédoanthracologiques des variations de la limite supérieure des arbres au cours de l'Holocène dans les Alpes françaises. Géogr Phys Quat 52:195-208

Théry-Parisot I (2001) Économie des combustibles au Paléolithique : Expérimentation, taphonomie, anthracologie. CNRS, Paris

Thomas PA, Polwart A (2003) Taxus baccata L. J Ecol 91:489-524

Tinner W, Lotter AF, Ammann B et al (2003) Climatic change and contemporaneous land-use phases north and south of the Alps 2300 BC to 800 BC. Quat Sci Rev 22:1,147-1,460

Touflan P, Talon B, Walsh K (2010) Soil charcoal analysis: a reliable tool for spatially precise studies of past forest dynamics: a case study in the French Southern Alps. Holocene 20:45-52

Uzquiano P, Allué E, Antolín F et al (2015) All about yew: on the trail of Taxus baccata in southwest Europe by means of integrated palaeobotanical and archaeobotanical studies. Veget Hist Archaeobot 24:229-247 
Vannière B, Galop D, Rendu C et 1 (2001) Feu et pratiques agro-pastorales dans les Pyrénées-Orientales : le cas de la montagne d'Enveitg (Cerdagne, Pyrénées-Orientales, France). Revue Géographique des Pyrénées et du Sud-Ouest 11:29-42

Verna C (2001) Le temps des moulines. Fer, technique et société dans les Pyrénées centrales $\left(\mathrm{XIII}^{\mathrm{e}}-\mathrm{XVI}^{\mathrm{e}}\right.$ siècles). Publications de la Sorbonne, Paris

Vernet J-L, Ogereau P, Figueira I et al (2001) Guide des charbons de bois préhistoriques et récents, SudOuest de l'Europe: France, Péninsule ibérique et Îles Canaries. CNRS, Paris 


\section{Figure legends}

Fig. 1 Location of the study area. A, location of the Ariège département in France; $\mathbf{B}$, location of the study area (black square) within the Vicdessos valley, the forêts Suc-et-Sentenac and Freychinède, the main places referred to, Vicdessos, Aulus-les-bains and Tarascon (red squares) and all previous palaeoecological studies cited in the text (orange circles); $\mathbf{C}$, topographical map of the study area, showing the three sample pits (black triangles) and charcoal kilns, both studied (brown squares) or not studied (white circles), by Léonel Fouedjeu. Histograms on the map give the relative amounts of charcoal of the main woody taxa identified from the studied kilns

Fig. 2 Photographs showing the difference between the two opposite sides of the valley, in terms of topography and vegetation. A, north side with sampling pits; $\mathbf{B}$, south side

Fig. 3 Detailed soil profiles of the pits Berna 1 to 3 . In Berna 1, a brown iron pan is visible at 10$20 \mathrm{~cm}$

Fig. 4 Photo showing of the three degrees of fungus hypha infestation, $\mathbf{0}$, none; $\mathbf{1}$, slight presence shown by arrows; $\mathbf{2}$, frequent presence

Fig. 5 Bar chart of the soil charcoal content from the pits Berna 1 to 3. Each horizontal bar corresponds to one layer. Amounts of charcoal are expressed in terms of anthracomass per layer (AL) and anthracomass per pit per taxon (APT), corresponding to the ratio of the weight of all charcoal from one taxon to the weight of all charcoal in one pit (AP). AL and APT are expressed in $\mathrm{g} / \mathrm{kg}$ of dry soil and are displayed on different scales because of wide differences between soils and layers. The numbers inside the black rectangles in the AL bar charts refer to the number of charcoal samples examined from each layer and from each pit

Fig. 6 Illustration of the three anatomical observation planes of Taxus baccata A, cross section; B, tangential section; $\mathbf{C}$, radial section. In $\mathrm{B}$ and $\mathrm{C}$, the spiral thickenings, typical anatomical criteria of this species, are clearly visible

Fig. 7 Distribution of degrees of hyphal infestation throughout the three pits. The NA (not assessed) category refers to cases where the degree of infestation could not be assessed due to the poor state of preservation of the charcoal

Fig. 8 Plot of the ten radiocarbon dates on charcoal in this study, shown as both BC/AD and cal $\mathrm{BP}$ 
Table 1 Distances in metres between the pedoanthracological pits Berna 1-3 and the nearest charcoal kilns

Table 2 The main taxa identified and total amounts of charcoal per layer (AL), per pit (AP) and per pit per taxon (APT), from each pit, Berna 1 to 3 , in $\mathrm{g} / \mathrm{kg}$ of dry soil. The numbers such as “5.48E-02" for each taxon represent ???

Table 3 Radiocarbon dates of 10 charcoal samples, 4 from Berna 1, 4 from Berna 3 and 2 from Berna 2 